\title{
History of dermatology and venereology in Serbia - part IV/2: Dermatovenereology in Serbia from 1919 - 1945, part 2
}

\author{
Bosiljka M. LALEVIĆ-VASIĆ ${ }^{1 *}$ and Marina JOVANOVIĆ ${ }^{2}$ \\ ${ }^{1}$ Institute of Dermatology and Venereology, Clinical Center of Serbia, Belgrade, Serbia \\ ${ }^{2}$ Clinic of Dermatovenereology Diseases, Clinical Center of Vojvodina, Novi Sad, Serbia \\ ${ }^{*}$ Correspondence: Bosiljka LALEVIĆ-VASIĆ, E-mail: labuba@eunet.rs
}

UDC 616.5(497.11)(091)"1919/1945"

UDC 616.97(497.11)(091)"1919/1945"

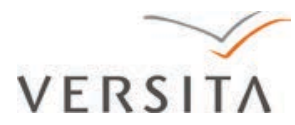

\section{Abstract}

After the First World War, Serbia was facing the lack of hospitals and physicians, and organization of the health care system was a real challenge. Both problems were closely associated with dermatovenereology. Between the two world wars, a great contribution to the development of Serbian dermatovenereology as a current discipline was given by Prof. Dr. Đorđe Đorđević, who was the first director of the Clinic for Skin and Venereal Diseases in Belgrade (1922 - 1935), and by his closest associate Prof. Dr. Milan Kićevac (1892 - 1940) who was his successor at the position of the director of the Clinic (1935 - 1940). In 1922, Prof. Dr. Đorđe Đorđević was the founder of two institutions significant for Serbian dermatovenereology: Clinic for Skin and Venereal Diseases, where he also acted as a director, and the Department of Dermatovenereology at the School of Medicine in Belgrade, where he was the first teacher of dermatovenereology. In 1927, Prof. Dr. Đorđe Đorđević initiated the foundation of the Dermatovenereology Section of the Serbian Medical Society, and he and his associate and successor, Prof. Dr. Milan Kićevac were the main organizers of the Association of Dermatovenereologists of Yugoslavia. With this Association, all other regional dermatovenereology sections in the County became parts of the Pan-Slavic Dermatovenereology Association. Prof. Dr. Đorđe Đorđević and Prof. Dr. Milan Kićevac also organized the First, Second and the Third Yugoslav Dermatovenereology Congresses (1927, 1928, and 1929), and in 1931, the Second Congress of Pan-Slavic Dermatovenereology Association. Their teamwork resulted in legislation concerned with health care, eradication of venereal diseases and prostitution, and finally with setting the foundation for professional and scientific dermatovenereology in Serbia. Prof. Đ. Đorđević investigated current problems of venereal diseases and organized professional expeditions in Serbia and Montenegro studying the expansion of syphilis. However, in his experimental work, Prof. M. Kićevac investigated photo-dermatoses and the IV venereal disease, at the same time pointing to immunological phenomena in streptococcal and staphylococcal infections.

Dr. Vojislav Mihailović (1879 - 1949) was a significant figure in Serbian dermatovenereology and acted as the Chief of the Department of Skin and Venereal Diseases within the General Public Hospital in Belgrade. His scientific papers and books on the history of dermatovenereology and general medicine had a great impact on the Serbian dermatovenereology. His books dealing with the history of dermatovenereology: "The History of Venereal Diseases till 1912" and "Out of the History of Sanitary Health Care in the Rebuilt Serbia from 1804 - 1860".

Associate Professor Dr. Sava Bugarski (1897 - 1945), a student of Prof. Dr. Kićevac and later the director of Clinic for Skin and Venereal Diseases in Belgrade (1940 - 1945), was engaged in the field of experimental dermatovenereology. Dr. Jovan Nenadović (1875 - 1952), one of the most eminent physicians in Novi Sad, took part in the foundation and work of the Dermatovenereology Section of the Serbian Medical Society as well as its honorary life president. In 1919, he founded the Dermatovenereology Department within the Novi Sad Hospital, as well as an Outpatient Dermatovenereology Clinic, outside the Hospital, although he was the director of both institutions.

In the period between the two world wars, among the most prominent physicians of the Military Sanitary Headquarters who contributed the development of dermatovenereology were the chiefs of the Dermatovenereology Department of the General Military Hospital in Belgrade: Major, later on, Brigadier General, Dr. Božidar Janković (1874 - 1936), and the Sanitary Brigadier General, Dr. Milivoje Pantić (1885 - 1959). Dr. B. Janković wrote important professional papers, among which the following are most significant: "Fight against Venereal Diseases in the Army" and "Treatment of Syphilis with Silber-Salvarsan."

Distinguished physicians of the military sanitary service, such as Dr. Petar Davidović, made significant contributions to the work of civilian dermatovenereology institutions of that time. In 1921, Dr. Petar Davidović was the director of the newly founded Venereal Department of the Niš Public Hospital, which was on a high professional level. 
T he First World War, invasion and post-war epidemics of infectious diseases in Serbia have caused a great loss of lives, both of civilians and of health professionals (1). Apart from the lack of hospitals, lack of physicians was a great problem affecting the health care system and dermatology in Serbia (1).

\section{Physicians}

The problem of the lack of physicians after the First World War was partly solved by recruiting physicians from the former Austro-Hungarian Empire, and from Russian immigrants, whereas soon after that School of Medicine was founded in Belgrade (2). Most Serbian medical students were educated abroad. For that reason, a substantial budget was approved for their scholarships in 1919 and 1920/1921. Out of this number of medical students, a remarkable number of future dermatologists returned to Serbia (1).

After the First World War, rapid development of dermatovenereology began in Serbia, mostly due to the appearance of two experts with outstanding organizing abilities, high scientific and research potentials and loyalty to their profession. They created legal standards, organized eradication of venereal diseases and prostitution and set foundations for professional and scientific dermatovenereology in Serbia. The first was Prof. Dr. Đorđe Đorđević and the other Prof. Dr. Milan Kićevac (Figure 1). Apart from their high professional and scientific reputation, they were favorite teachers to their students.

Prof. Dr. Đorđe Đorđević (1885 - 1935) graduated from medicine in 1909 in Vienna. During his studies, he worked at the University Clinic for Skin and Venereal Diseases with Prof. Finger. After graduation, he was appointed Assistant at the Dermatovenereology Clinic in Innsbruck, whereas in 1912 he moved to Zagreb where he had a private practice, but also worked at the Department of Skin Diseases of the "Hospital of Brothers of Mercy".

In 1918, after the war, he moved to Belgrade and became the Head of the newly established Outpatient Service for Skin and Venereal Diseases (OSSVDs) (3). In 1922, he was the main founder of two institutions significant for Serbian dermatovenereology: Clinic for Skin and Venereal Diseases (CSVDs), being its director as well, and the Department of Dermatovenereology at the School of Medicine in Belgrade, where he was the first teacher of dermatovenereology (4). He was appointed Associate Professor of dermatovenereology in 1923, a Full Professor in 1933, and a Vice Dean in the academic year 1934/35 (5).

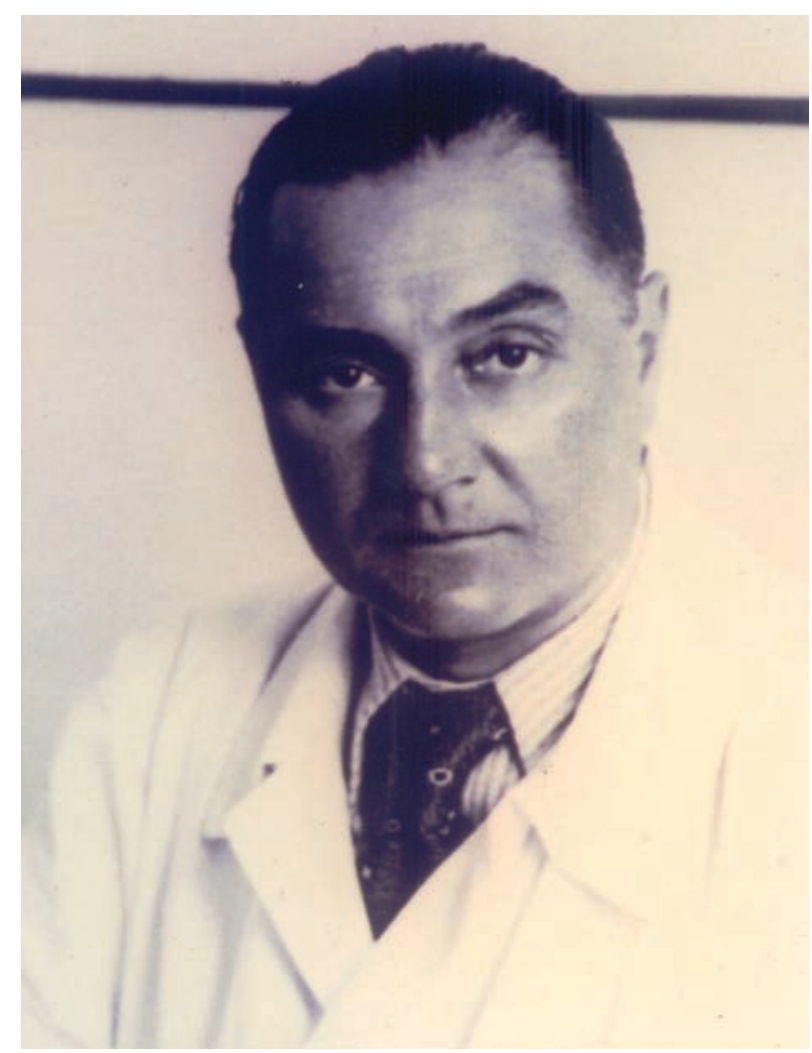

Figure 1. Prof. Dr. Milan Kićevac

In 1927, Prof. Dr. Đorđe Đorđević was one of the founders and the first president of the Dermatovenereology Section of the Serbian Medical Society (DVS SMS) (6).

He was especially interested in solving one of the most serious problems of that time - treatment of syphilis (SY), while his research in gonococcal infections anticipated non-specific urethritis $(3,4)$. He was involved in socio-medical health care and organized professional expeditions which investigated the expansion of SY, as well as the general health status of people in the East Serbia, Macedonia, Sandžak, and Montenegro. He had published 49 papers, out of which 19 in international journals.

Prof. Dr. Đorđe Đorđević was an honorary or regularmember of eightEuropean Dermatovenereology Associations (3). He died unexpectedly, a few days after his $50^{\text {th }}$ birthday, in 1935 .

Prof. Dr. Milan Kićevac (1892 - 1940) (Figure 1) started studying medicine in Vienna, but completed his studies in Bern. He was an "Assistant Étranger" in Paris, assistant to Milian, and he attended histological, clinical and microbiological courses of Milian, Civatte and Sabouraud (7). 


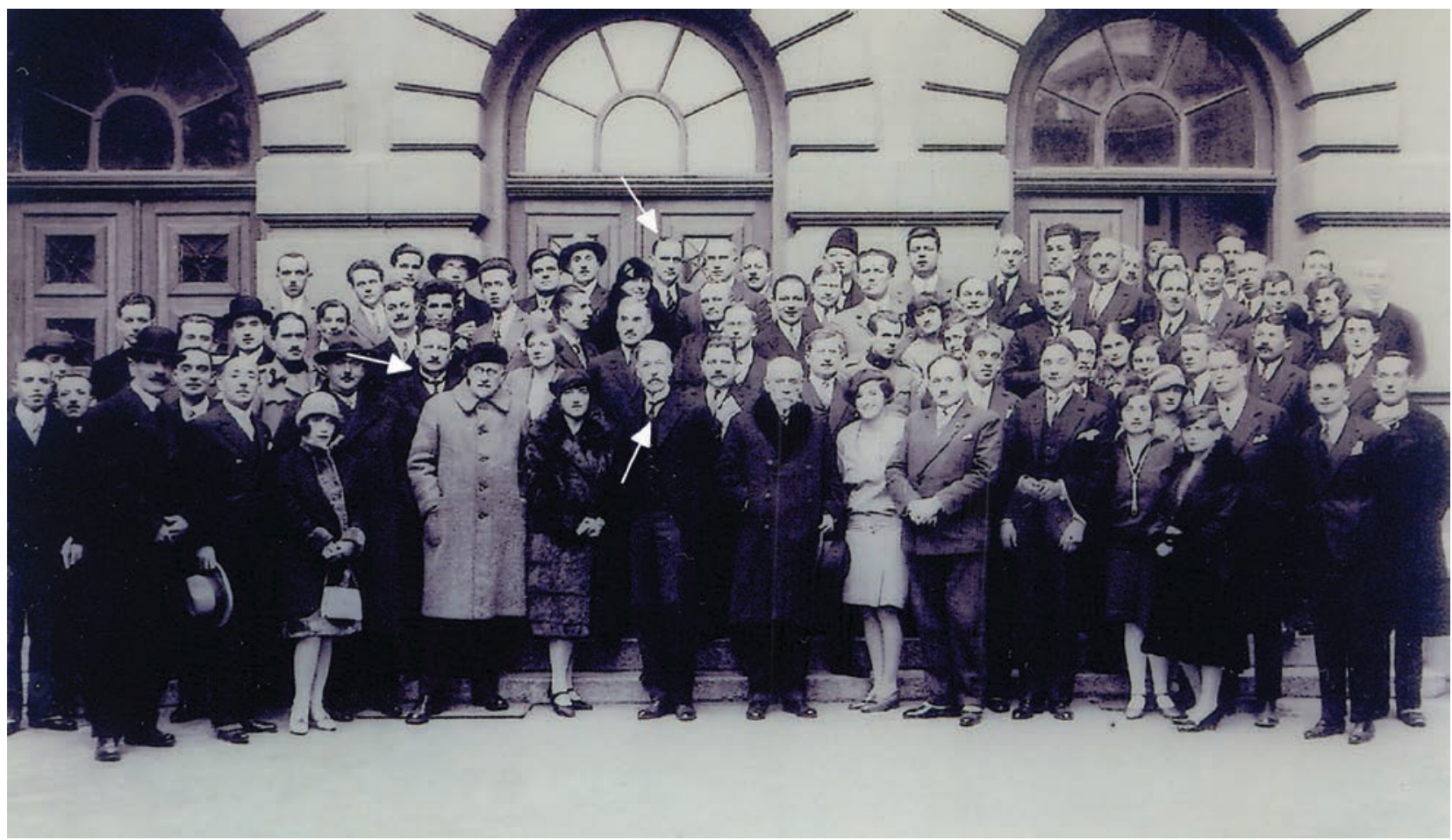

Figure 2. Constituent Assembly of the Yugoslav Association of Dermatovenereologists in Belgrade in 1927: Dr. Jevrem Žujović is standing in the first row (indicated by an arrow); Prof. Dr. Đorđe Đorđević, is standing in the second row (indicated by an arrow); Prof. Dr. Milan Kićevac is standing in the last row (indicated by an arrow).

Prof. Kićevac was the first, enthusiastic and loyal associate and later the successor of Prof. Đorđević at all his positions, but also a researcher who was the founder of our experimental dermatovenereology. He accepted the Sabouraud's motto: "In order to uncover the truth, it is necessary to attack axioms" At the same time as Frei, he investigated allergic reactions to gland biopsy in the fourth venereal disease (7).

Prof. Dr. Milan Kićevac was famous for his investigations in the field of photo-dermatoses, and his papers were well known and cited. He pointed to the significance of sunlight in the development of dermatitis pratensis, using terms "exogenous and endogenous photo-catalysts and photosensibilizators". He was among the first to write about "streptococcidal and staphylococcidal agents", and ahead of his time, he pointed to the importance of immunologic phenomena in bacterial infections ( 7 , 8). He had published 84 papers, mostly in French journals, which were often cited; after his early death, he left a number of unpublished papers and a textbook in dermatovenereology. Unfortunately, they had been lost in the whirlwind of war. He was a corresponding or full member of 8 European Dermatovenereology Associations. He died in 1940, at the age of 49 (7).
During their work, Prof. Dr. Đorđe Đorđević and Prof. Dr. Milan Kićevac had a leading role in the organization of dermatovenereology service. Their work was closely related so that we will write about them and their work at the same time. Owing to their work dermatovenereology in Serbia had developed into a modern discipline with international reputation. They organized activities for eradication of venereal diseases and prostitution. Prof. Dr. Đorde Đordević had initiated creation of the Belgrade Dermatovenereology Moulage Collection, but they worked on it together (4). After the foundation of the Dermatovenereology Section (DVS) of the Serbian Medical Society (SMS), in 1927 they were the main organizers of the Association of Dermatovenereologists of Yugoslavia (ADVY) (Figure 2) whose president was Dr. Jevrem Žujović (9). The Association included all dermatovenereology sections of the Kingdom of the Serbs, Croats and Slovenes (SCS) of that time, and owing to that, they became members of the PanSlavic Association of Dermatovenereologists (PSADVs) founded in Prague at that time (10). They and their associates organized the First (1927), Second (1928) and Third (1929) Yugoslav Dermatovenereology Congresses $(11,12,13)$. After the First Congress 
of the PSADVs, held in Warsaw in 1929, Prof. Dr. Đorđe Đorđević became its president, while Dr. Milan Kićevac, Assistant at that time, was appointed a Secretary of the Association. In 1931, they organized the Second Congress of the PSADVs in Belgrade, which was attended, apart from the members of Slavic national associations, by outstanding dermatologists from France, Romania and Greece. The Congress was very successful with international participation (13).

Dr. Vojislav Mihailović (1879 - 1949) (Figure 3) was the Head of the Department of Skin Diseases and Syphilis (DSDS) within the General Public Hospital $(\mathrm{GPH})$ in Belgrade (1927 1941). He graduated from medicine in 1904 in Graz (14). Among his first publications was a monograph on venereal diseases titled: "Venereal Diseases: Etiology, Course and Eradication". Its second extended edition was published in 1924 (15). Apart from numerous professional papers (15), he was interested in the history of medicine and wrote two books of great significance. The first one: "The History of Venereal Diseases in Serbia up to 1912", was the first and only book on the history of venereal diseases in our country (16). The second book: "Out of the History of Sanitary Health Care in the Rebuilt Serbia from 1804 1860 ", presented the development of medicine in our country in the first half of the $19^{\text {th }}$ century (17). Both

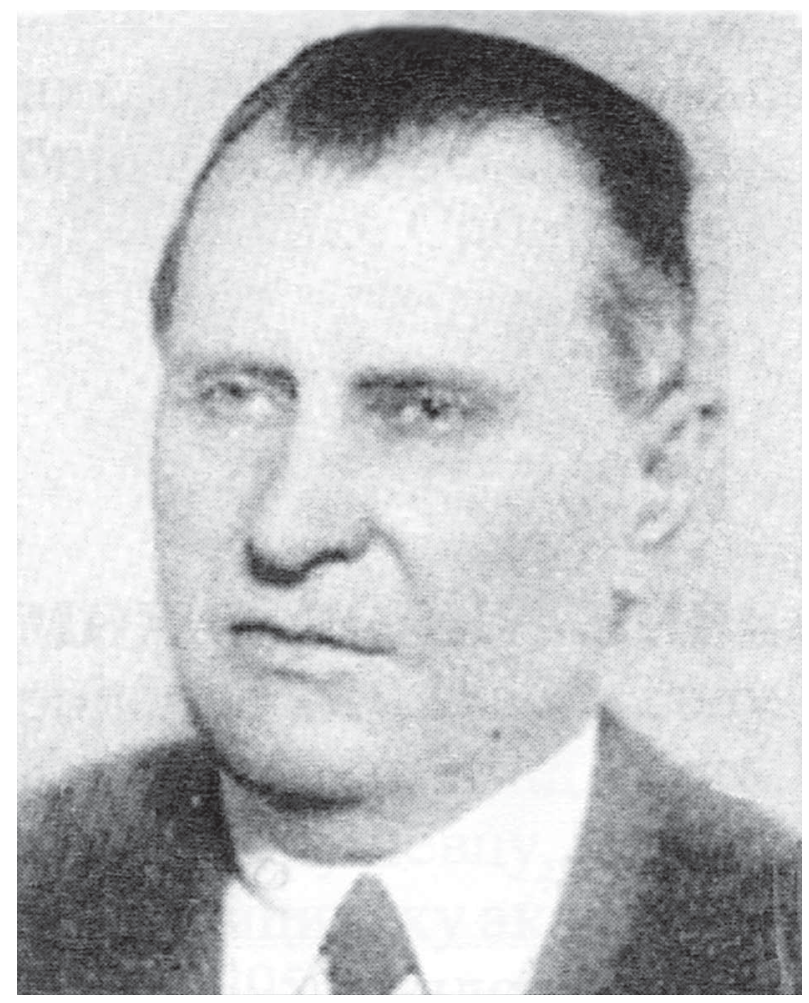

Figure 3. Dr. Vojsilav Mihajlović

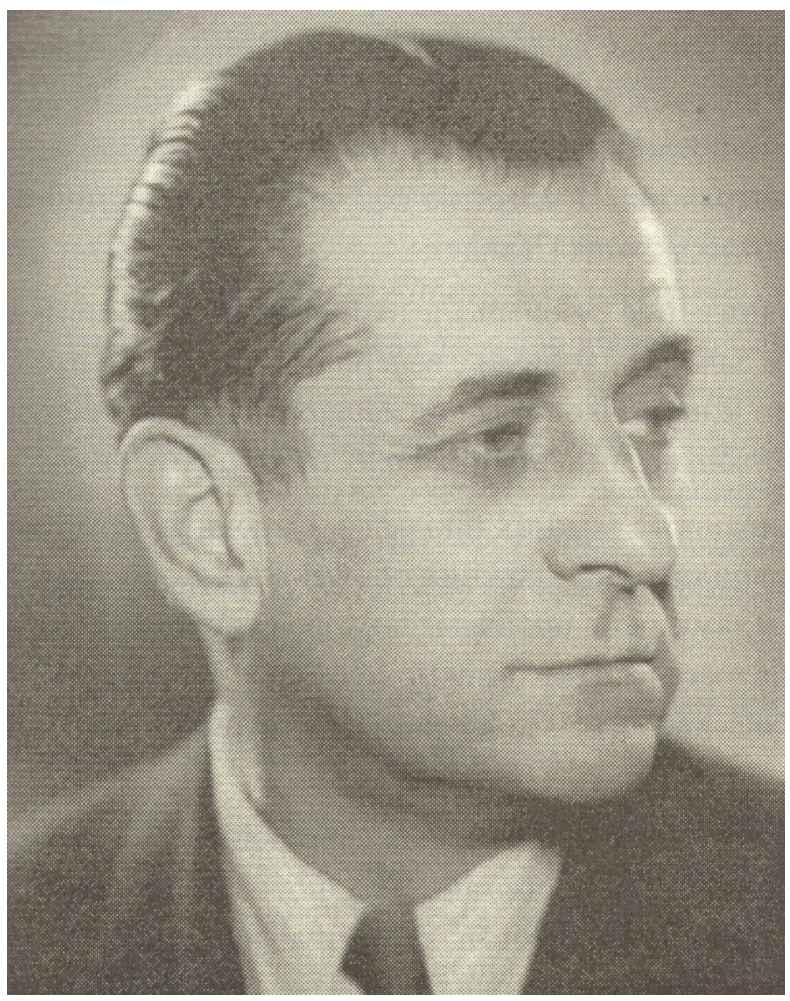

Figure 4. Associate Professor, Dr. Sava Bugarski

books were written based on original archive documents, attached in its entirety, translated into the current Serbian language and thus they are indispensable in the study of this field of medicine. Still a student, he translated Eugene Brieux play "Damaged Goods" about the painful life of people with syphilis (16).

Associate Professor, Dr. Sava Bugarski (1897 - 1945) (Figure 4) started studying medicine in Zagreb, but continued and graduated in Graz in 1924. He specialized in dermatovenereology at the CSVDs in Belgrade (18). In 1926, he was appointed an Assistant, and in 1939 as an Associate Professor at the Department of Dermatovenereology at the School of Medicine in Belgrade (18). He was the director of the CSVDs with occasional interruptions during the occupation from 1940 to 1945 . Being a student of Prof. Kićevac, he was interested in experimental dermatovenereology and investigated effects of sinlight on certain dermatoses. He studied effects of anti-syphilis therapy on the T. pallidum virulence on experimental animals. Results of his studies were published in national and international professional journals. He also died unexpectedly, in 1945, before the age of $50(18,19)$.

Dr. Jovan Nenadović (1875 - 1952) (Figure 5) was the first Serbian dermatovenereologist 


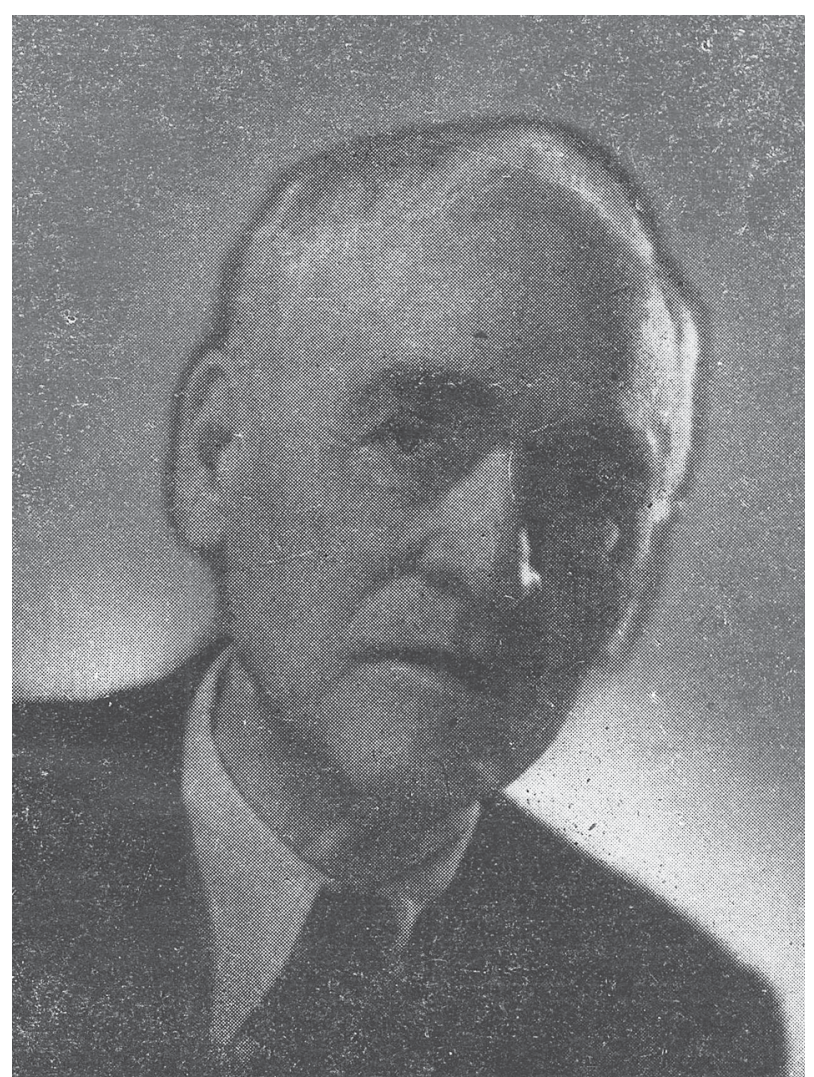

Figure 5. Dr. Jovan Nenadović

in Vojvodina. In 1900, he graduated from the Medical University of Graz, and specialized in dermatovenereology in Vienna, working with eminent scientists such as Kaposi and Finger. After the First World War, in 1918, when he returned to Novi Sad, there was neither Hospital nor Department for the treatment of patients with skin and venereal diseases. Then he founded the Department of Skin and Venereal Diseases of the GPH in Novi Sad with 100 beds, and outside the hospital an independent Public Outpatient Service for Skin and Venereal Diseases, for free of charge treatment of patients with venereal diseases. Dr J. Nenadović was the director of both institutions (20, 21). Later, he became the director of the GPH in Novi Sad and the first president of the Danube Banovina Medical Association. He had a private medical office with all the necessary state-of-the-art equipment (18).

$\mathrm{He}$ was one of the initiators and founders of the DVS of the SMS and its honorary life president. He was engaged in humanitarian work and initiated all significant humanitarian, social and cultural events in Novi Sad. He was also one of the greatest humanists and among the most eminent physicians of that time (21).
Dr. Božidar S. Janković (1874-1936), a Sanitary Brigadier General, was awarded a great number of war decorations, among which the following two are most important: Gold medal for best service and Gold medal for bravery; he graduated from medicine in St. Petersburg, and in the period from $1908-$ 1910, he was an intern at the GPH in Belgrade (22). As a Reserve Major, after the end of the First World War, he became a director of the Dermatovenereology Department (DVD) of the General Military Hospital $(\mathrm{GMH})$ in Belgrade (23). In 1920, he joined the army of the Kingdom of SCS (22).

He specifically dealt with one of the greatest health problems of that time - venereal diseases. Among his published works, two are of great significance: a book: "The Fight against Venereal Diseases in the Army" (24) and "On the Treatment of Syphilis with Silber-Salvarsan" (25). Later, as a Colonel, he was the Medical Officer of the Third Army Area, and in 1934 he was promoted to the rank of a Sanitary Brigadier General $(5,25)$.

Dr. Milivoje Pantić (1885-1959) (Figure 6), a Sanitary Brigadier General, graduated from the School of Medicine in Vienna in 1900. After the First World War, as a Major, he became the director of the DVD of the Permanent Military Hospital of the First

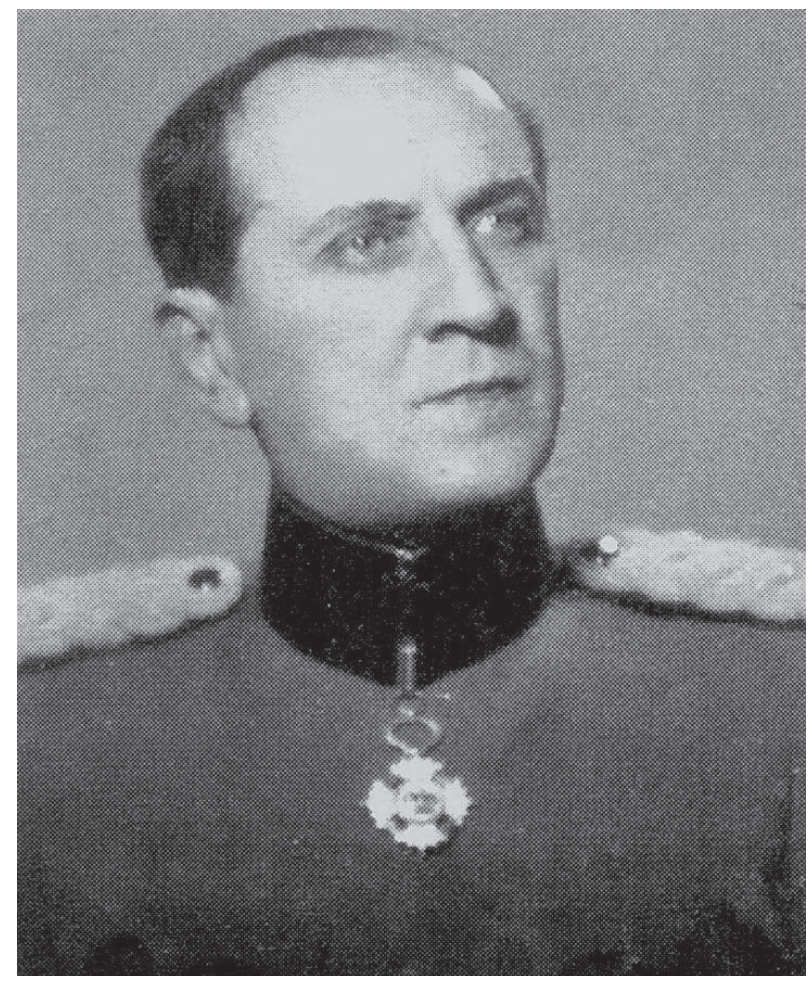

Figure 6. Dr. Milivoje Pantić 
Military Area, and till the beginning of the Second World War he was the director of the DVD of the GMH in Belgrade $(23,26)$.

Dr. Petar Davidović (1884 - ?, after 1933), was born in Srem, Vojvodina. He attended the Karlovačka High School and graduated from School of Medicine in Prague (27). In 1921, after being demobilized, he became the Head of the Department for Skin and Venereal Diseases of the City Hospital in Niš, up to then directed by Dr. Eva Haljecka, general practitioner. The work of this Department was at a high professional level, so medical students had been able to perform their practice in that institution, whereas their knowledge and skills were estimated by the director of the Department (28).

To be continued.

\section{Abbreviations}

ADVY - Association of Dermatovenereologists of Yugoslavia CSVDs - Clinic for Skin and Venereal Diseases DSDS - Department of Skin Diseases and Syphilis

DVD - Dermatovenereology Department

DVS - Dermatovenereology Section

GMH - General Military Hospital

GPH - General Public Hospital

OSSVDs - Outpatient Service for Skin and

Venereal Diseases

PSADVs - Pan-Slavic Association of

Dermatovenereologists

SCS - Serbs, Croats and Slovenes

SMS - Serbian Medical Society

SY - Syphilis

\section{References}

1. Milovanović V. Editor: Medicinski godišnjak Kraljevine Jugoslavije (Annual Medical Report of the Kingdom of Yugoslavia). Beograd: Jugoreklam K. D; 1933.

2. Ignjatović M. Srpska ratna vojna doktrina u ratovima 19121918 (Serbian war surgical doctrine 1912 - 1918). Vojnosanit Pregl 2008;65(Suppl):49-58.

3. Kićevac M. In Memoriam. Prof. Đ. Đorđević. Naučni i stručni rad Prof. Đorđa Đorđevića (Scientific and professional work of Prof. Đ. Đorđević). Med Pregl 1936;11(4):61-3.

4. Kićevac M. Klinika za kožne i venerične bolesti (Clinic for Skin and Venereal Diseases). U: Medicinski fakultet Univerziteta u Beogradu 1920-1935 (In: School of Medicine of the Belgrade University from 1920 - 1935). Beograd: Medicinski fakultet; 1935. p. 125-31.

5. Čolović R. Djordjević Djordje. U: Popov Č. Editor. Srpski biografski rečnik 3 D-Z (Serbian biographical dictionary 3 D Z.). Novi Sad: Matica Srpska - Miro Vuksanović; 2007. p. 540-1.
6. Zapisnik II redovne godišnje skupštine Dermatovenerološke sekcije SLD (Minutes of the Second regular assembly of the Dermatovenereology Section of the SMS). Srp Arh Celok Lek 1928;30(3):232-3.

7. Bugarski S. In Memoriam. Prof. dr Milan Kićevac. Med Pregl 1940;15(4):73-5.

8. Kićevac M. Fotodermatoze biljnog porekla (Photodermatoses of plant origin). Med Pregl 1939;14 (4):61-6.

9. Osnivačka skupština Jugoslovenskog derma-tološkog društva (Founding meeting of the Association of Dermatovenereologists of Yugoslavia). Srp Arh Celok Lek 1928;30(11):931-42.

10. Skup Jugoslovenskih dermatologa i venerologa i osnivanje Jugoslovenskog dermatovenerološkog društva (Meeting of Yugoslav dermatologists and venereologists and foundation of the Association of Dermatovenereologists of Yugoslavia). Srp Arh Celok Lek 1928;30(2):147-9.

11. M. K. II skup Jugoslovenskih dermatologa i venerologa (The second meeting of Yugoslav dermatologists and venereologists). Med Pregl 1929;4(1):38.

12. Kićevac M. III Skup Jugoslovenskih dermatologa i venerologa (The third meeting of Yugoslav dermatologists and venereologists). Med Pregl 1930;5(1):31-4.

13. Ilić S. II Kongres Sveslovenskog dermatološkog Saveza (The second congress of the Pan-Slavic Dermatology Association). Med Pregl 1931;6(8):229-34.

14. Stanojević V. Likovi i dela istaknutih lekara od osnivanja Srpskog lekarskog društva do danas (Characters and works of prominent physicians since the foundation of SMS to date). U: Đurić D, i sar. Srpsko lekarsko društvo: Spomenica 18721972 (Serbian Medical Society: Memorial Book 1872-1972). Beograd: Srpsko lekarsko društvo; 1972:159-254.

15. Mihajlović V. Polne bolesti: njihov postanak, tok i suzbijanje (Venereal Diseases: Etiology, Course and Eradication). 2nd ed. Beograd: Vuk Karadžić; 1924.

16. Mihailović V. Istorija polnih bolesti u Srbiji do 1912. godine (The history of venereal diseases in Serbia till 1912). Beograd: Biblioteka centralnog higijenskog zavoda; 1931.

17. Mihailović V. Iz istorije saniteta u obnovljenoj Srbiji od $1804-1860$ (Out of the history of health care in the rebuilt Serbia from 1804 - 1860). Beograd: Srpska Akademija nauka CLXXX; Odeljenje medicinskih nauka 4; 1951.

18. Milanović M. Biografski leksikon: poznati srpski lekari (Biographical lexicon: Eminent Serbian physicians). Beograd: Milanović Milena; 2005.

19. Arhivski dokumenat (Archive document). Arhiv Srbije, F I; $1856 / 45$.

20. V. J. Pedesetogodišnjica lekarskog i kulturnog rada Dr Jovana Nenadovića (50th Anniversary of medical and cultural work of Dr. Jovan Nenadović). Med Pregl 1951;4(9-10):1-3.

21. V. K. In memoriam. Dr Jovan Nenadović. Med Pregl 1953;6 (3):201-2.

22. Nedok AS. Janković Božidar. U: Popov Č, urednik. Srpski biografski rečnik 3 D-Z (Serbian biographical dictionary 3 D Z). Novi Sad: Matica Srpska; 2007. p. 269.

23. Dinić MŽ, Kandolf-Sekulović L, Zečević RD. Sto godina dermatovenerologije u Vojsci Srbije (A hundred years of dermatovenereology in the Serbian Army). Vojnosanit Pregl 2010;67(1):73-6. 
24. Janković BS. Borba s veneričnim bolestima u vojsci (Management of venereal diseases in the army). Beograd: Ministarstvo vojno i mornarice; 1923.

25. Janković B. O lečenju sifilisa silbersalvarsanom (On the therapy of syphilis by silber-salvaran). Srp Arh Celok Lek 1921;21(9):487-502.

26. Bjelajac MS. Generali i Admirali Kraljevine Jugoslavije 1918-1941. (Generals and Admirals of the Kingdom of Yugoslavia from 1918 -
1941). Beograd: Institut za noviju istoriju Srbije, Dobra d.o.o; 2004. 27. Nedok AS. Davidović Petar. U: Popov Č, urednik. Srpski biografski rečnik 3 D-Z (Serbian biographical dictionary 3DZ). Novi Sad: Matica Srpska; 2007. p. 51.

28. Krstić S. 80 godina službe i 20 godina Klinike za kožne i polne bolesti u Nišu (80th Anniversary of the Service and $20^{\text {th }}$ Anniversary of the Clinic for Skin and Venereal Diseases in Niš). Niš: Univerzitetski klinički centar, Klinike za kožne i polne bolesti; 1991. 